IZA DP No. 7830

STEM Graduates, Human Capital Externalities, and Wages in the U.S.

John V. Winters

December 2013 


\title{
STEM Graduates, Human Capital Externalities, and Wages in the U.S.
}

\author{
John V. Winters \\ Oklahoma State University \\ and IZA
}

Discussion Paper No. 7830

December 2013

\author{
IZA \\ P.O. Box 7240 \\ 53072 Bonn \\ Germany \\ Phone: +49-228-3894-0 \\ Fax: +49-228-3894-180 \\ E-mail: iza@iza.org
}

Any opinions expressed here are those of the author(s) and not those of IZA. Research published in this series may include views on policy, but the institute itself takes no institutional policy positions. The IZA research network is committed to the IZA Guiding Principles of Research Integrity.

The Institute for the Study of Labor (IZA) in Bonn is a local and virtual international research center and a place of communication between science, politics and business. IZA is an independent nonprofit organization supported by Deutsche Post Foundation. The center is associated with the University of Bonn and offers a stimulating research environment through its international network, workshops and conferences, data service, project support, research visits and doctoral program. IZA engages in (i) original and internationally competitive research in all fields of labor economics, (ii) development of policy concepts, and (iii) dissemination of research results and concepts to the interested public.

IZA Discussion Papers often represent preliminary work and are circulated to encourage discussion. Citation of such a paper should account for its provisional character. A revised version may be available directly from the author. 
IZA Discussion Paper No. 7830

December 2013

\title{
ABSTRACT
}

\section{STEM Graduates, Human Capital Externalities, and Wages in the U.S.}

\begin{abstract}
Previous research suggests that the local stock of human capital creates positive externalities within local labor markets and plays an important role in regional economic development. However, there is still considerable uncertainty over what types of human capital are most important. Both national and local policymakers in the U.S. have called for efforts to increase the stock of college graduates in science, technology, engineering, and mathematics (STEM) fields, but data availability has thus far prevented researchers from directly connecting STEM education to human capital externalities. This paper uses the 2009-2011 American Community Survey to examine the external effects of college graduates in STEM and non-STEM fields on the wages of other workers in the same metropolitan area. I find that both types of college graduates create positive wage externalities, but STEM graduates create much larger externalities.
\end{abstract}

JEL Classification: J24, R23

Keywords: $\quad$ human capital externalities, STEM, wage growth, agglomeration

Corresponding author:

John V. Winters

Department of Economics and Legal Studies

331 Business Building

Oklahoma State University

Stillwater, OK 74078-4011

USA

E-mail: jvwinte@okstate.edu

\footnotetext{
* The author thanks Barry Hirsch, Martijn Kobus, Dan Rickman, Dave Sjoquist, workshop participants at Oklahoma State University and session participants at the 2013 North American Meetings of the Regional Science Association International for helpful comments. The usual disclaimer applies.
} 


\section{Introduction}

Previous researchers have suggested that the local stock of human capital in an area creates positive externalities for local labor market outcomes (Rauch 1999; Moretti 2004a,b,c; Shapiro 2006; Iranzo and Peri 2011; Winters 2011a, 2013) and leads to future employment and population growth (Glaeser, Scheinkman and Shleifer 1995; Glaeser and Saiz 2004; Simon 1998, 2004; Simon and Nardinelli 2002). ${ }^{1}$ In particular, areas with a high percentage of high human capital workers have higher wages, and this is true for both high human capital and low human capital workers and controlling for individual worker characteristics. Importantly though, there is still considerable uncertainty over what types of human capital are most important for regional economic development. Moretti (2004b), Glaeser (2005), and many others measure local human capital levels by the share of the local population that has completed a bachelor's degree. However, Florida (2002) suggests that the share of workers in creative occupations plays the most important role for regional economic development. Glaeser (2005) points out that these human capital measures are closely related conceptually and difficult to separate empirically. Thus, there is wide agreement that human capital is important, but there is great uncertainty over what type of human capital matters most.

At the same time, both national and local policymakers in the U.S. have called for efforts to increase the stock of college graduates in science, technology, engineering, and mathematics (STEM) fields (National Academies 2010). STEM fields are thought to be major drivers of innovation and therefore have important consequences for long run economic growth and individual welfare (Atkinson and Mayo 2010). There is a widespread belief that the nation is

\footnotetext{
${ }^{1}$ Reviews of this literature are offered by Moretti (2004a), Lange and Topel (2006), Henderson (2007), and Storper and Scott (2009). There is also a large literature examining why areas differ in human capital levels and how they can attract high human capital workers (Florida 2002; Berry and Glaeser 2005; Gottlieb and Joseph 2006; Whisler et al. 2008; Winters 2011b; Abel and Deitz 2012a; Brown and Scott 2012; Miguélez and Moreno 2013).
} 
experiencing a STEM shortage and state and local areas generally believe that their economic fortunes depend on their ability to produce, recruit, and retain STEM graduates.

Given the widespread interest in STEM graduates by policymakers and the general public, one might expect there to be a large research literature investigating the benefits that STEM graduates generate for their local economies. Unfortunately, this is not the case. A lack of available data has thus far prevented researchers from directly connecting STEM education to regional economic development. Population surveys like the Current Population Survey and decennial census do not ask respondents about their college major, and national surveys of college graduates that ask about college major do not typically have sufficiently large sample sizes to produce reliable estimates for most geographic areas. However, beginning in 2009 the American Community Survey (ACS) began asking college graduates to report the major field in which they earned their bachelor's degree. The ACS samples one percent of the U.S. population each year and now makes it possible to compute fairly precise estimates of the percentage of STEM graduates for most metropolitan areas.

This paper uses the 2009-2011 ACS to examine the external effects of college graduates in STEM and non-STEM fields on the wages of other workers in the same metropolitan area. I examine how these human capital measures separately affect non-college graduates, STEM graduates, and non-STEM graduates. I find that both types of college graduates create positive wage externalities, but STEM graduates create much larger external benefits. There is some concern that the results may not measure causal effects, but the pattern of results is highly suggestive of external benefits of having additional STEM graduates in the local area. This study supports efforts by policymakers to increase the stock of STEM graduates, both regionally and nationally. 


\section{Background on Human Capital Externalities, the Creative Class, and STEM Graduates}

There is a general consensus among researchers and policymakers that human capital is important for regional economic growth and development but no consensus on which types of human capital are the most important. Most research has measured human capital in one of two ways: 1) using traditional education measures, most notably the percentage of the local population that has completed a bachelor's degree and 2) based on occupation measures, most notably the percentage of workers employed in creative occupations.

Both measures have some intuitive appeal. Individuals acquire education largely because it is a human capital investment that increases their knowledge and skills, makes them more productive in the labor force, and gives them higher earnings. One person's education is also thought to benefit other people through a number of mechanisms including the creation of new ideas that lead to new production processes, the transmission of knowledge and skills from one worker to another, increased demand for locally produced goods and services, and imperfect substitutability of skilled and unskilled labor (Moretti 2004a,b). The average education level in an area has been shown to increase wages of other workers and predict future population and employment growth. The relationships are especially strong when measuring human capital by the percentage of the local population with a college degree.

Researchers in the creative class camp note that college degrees are incredibly heterogeneous in the skills that they impart and there is some skepticism that all types of education improve labor productivity. Many college graduates earn degrees in fields that seem unlikely to substantially increase the development of skills highly valued in the labor market. Many take jobs that use their education very little, and some take jobs for which they are 
overeducated (Robst 2007a,b; Abel and Deitz 2012b). Furthermore, part of the value of a college education is that it is a credential that signals one's innate ability to employers, independent of the knowledge and skills gained. Thus, many types of education benefit the recipient without creating external benefits for others in the same area. As such a broad measure like the share of the population with a college degree may fail to fully capture the most important components of human capital for regional economic development (Rodríguez-Pose and VilaltaBufi 2005).

Florida (2002) and others suggest that workers in creative occupations are the most important for economic development because they are the ones most responsible for creating a local atmosphere of creativity that leads to new ideas. These new ideas then often lead to new products and more efficient production processes. These new products and processes lead to higher productivity and hence higher wages for other workers in the local labor market. Therefore, creativity is thought by many to be the key element of human capital because it encourages innovation that fuels technological growth.

Creative class measures have some limitations as well. Measuring the creative class is complicated by disagreement over which occupations are members of the creative class. Florida (2002) defines the creative class as workers in occupations that "engage in complex problem solving that involves a great deal of independent judgment and requires high levels of education or human capital." This includes occupations in science, technology, engineering, and math (STEM), but also includes occupations in the fields of education, library administration, art, entertainment, media, management, finance, law, healthcare, and high end sales. Defining occupations as creative or not is an inherently subjective process, and notwithstanding Florida's (2002) delineation, there is no obvious and intuitive benchmark definition like with education. 
McGranahan and Wojan (2007) suggest a narrower measure of the creative class and find it to be more strongly associated with regional development. Communian, Faggian, and Li (2010), and Abreu et al. (2012) note that the Bohemian component of the creative class is quite different from the rest and experiences significantly worse employment outcomes. Florida, Mellander and Stolarik (2008) try to decompose the creative class into several occupation groups and examine the bivariate correlation each has with average local wages and incomes. However, average wages and incomes reflect both direct and indirect effects. A high density of high earning occupations should increase average wages directly because of composition effects. Much more interesting is whether highly skilled workers indirectly benefit other workers in the same area, i.e., do they have positive external effects on the wages of workers in other occupations? This is an important issue that is largely overlooked by numerous researchers using average wages.

A large literature has examined the effects of either traditional or creative class human capital measures on regional development. ${ }^{2}$ A few studies have attempted to separate out the competing effects of education-based and creative class measures of human capital (e.g., Glaeser 2005; Donegan et al. 2008; Mellander and Florida 2007; Florida, Mellander and Stolarik 2008; Faggian, Partridge and Malecki 2011; Marrocu and Paci 2012). Collectively, studies trying to separate the effects offer mixed results, in part because the two measures are highly correlated and both measures have some important limitations.

The current study does not intend to resolve the debate over whether higher education or the creative class is the more important driver of regional development. Instead, this study examines the separate effects of two specific types of higher education: STEM graduates and

\footnotetext{
${ }^{2}$ Related strands of the regional economic development literature have also considered the effects and determinants of spatial differences in high-tech industries (Echeverri-Carroll and Ayala 2009; Fallah, Partridge, and Rickman 2013), innovation (Rodriguez-Pose 1999; Rodríguez-Pose and Crescenzi 2008; Crispin, Saha, and Weinberg 2010; Bauer, Schweitzer, and Shane 2012; Paci and Marrocu 2013), and entrepreneurship (Acs and Armington 2006; Glaeser, Kerr, and Ponzetto 2010; Stephens and Partridge 2011; Stephens, Partridge, and Faggian 2013).
} 
non-STEM graduates. STEM graduates are an important component of both creative class and higher education measures, but some non-STEM graduates are in creative occupations as well.

The motivation for looking at the separate effects of STEM graduates and non-STEM graduates comes from popular perceptions and government policies that view STEM education as critical for both national and regional economic growth. ${ }^{3}$ STEM graduates have been shown to have higher average earnings than non-STEM graduates (Sjoquist and Winters 2013), but we currently know very little about how these two types of college graduates affect regional economies more generally. In particular, it is unknown how these two types of graduates affect the wages of other workers. The general expectation is that STEM graduates might be more beneficial but there is no direct empirical evidence to support this. Regional differences in the stocks of STEM and non-STEM graduates have been previously difficult to measure, but the addition of college major to the American Community Survey in 2009 has made it possible.

An alternative to measuring the effects of STEM graduates is to measure the effects of STEM occupations as in Peri, Shih and Sparber (2013). These are similar questions, but there are some subtle and important differences. Not all STEM graduates work in STEM occupations and not all workers in STEM occupations have degrees in STEM fields. The current study focuses on education-based measures of STEM for important reasons. First, calls by policymakers for more STEM most commonly call for more STEM graduates. Similarly, at the margin it is likely easier for policy to directly increase STEM education than STEM occupations (without an increase in STEM education) because policymakers have greater influence over the inputs into the education process. However, despite the different measures, the current study and Peri, Shih and Sparber (2013) are in many ways complementary.

\footnotetext{
${ }^{3}$ In addition to the benefits to economic growth and development, STEM graduates also play a vital role in developing innovations related to national defense, healthcare, disease prevention, climate change, etc. These benefits are primarily national but certainly benefit regions within nations as well.
} 


\section{Empirical Framework}

This paper uses the 2009-2011 American Community Survey (ACS) microdata to examine the external effects of college graduates in STEM and non-STEM fields on the wages of other workers in the same metropolitan area. The data are obtained from the IPUMS (Ruggles et al. 2010) and each year includes a one percent sample of the U.S. population. The ACS contains detailed information on individual earnings, employment, education, and demographic characteristics and in 2009 began asking college graduates to report the major field in which they earned their bachelor's degree.

The ACS also reports an individual's geographic location, but the Census Bureau's data confidentiality procedures prevents one from identifying counties and metropolitan areas with a population less than 100,000 people. Smaller areas are combined with other nearby areas. The smallest identifiable geographic area in the public use microdata is the PUMA. Some PUMAs combine parts of both metropolitan and non-metropolitan areas. I assign such PUMAs to a metropolitan area if more than half of the PUMA's population lives in the metro area. PUMAs that are predominantly non-metropolitan are dropped from the sample. This results in 325 metropolitan areas in the analysis.

I restrict the sample to full-time full-year workers between ages 25 and 55 with unallocated annual wage income; full-time is defined as 40 or more hours per week and full-year is defined as 50 or more weeks per year. ${ }^{4}$ The external effects of human capital are estimated separately for three types of workers: 1) workers whose highest education is less than a

\footnotetext{
${ }^{4}$ The ACS codes weeks worked into interval bands. The highest interval is 50-52 weeks, and 76 percent of all workers are in this band. The interval bands are much wider for part-year workers. One could also examine partyear workers, but because of the wide bands it is difficult to surmise how much of annual wage differences are due to labor supply differences and how much is due to productivity/hourly wage differences.
} 
bachelor's degree, 2) workers with a bachelor's degree in a STEM field, and 3) workers with a bachelor's degree in a non-STEM field. The external effects of human capital are examined by regressing the $\log$ of real ${ }^{5}$ annual wage income, $W$, for worker $i$ in area $j$ on a set of individual characteristics, $X$, and a set of metropolitan area characteristics, $Z$, i.e., I estimate:

$$
\ln W_{i j}=X_{i j} \beta+Z_{j} \theta+\varepsilon_{i j}
$$

Individual characteristics are intended to control for observable differences in workers across areas and include variables commonly found to affect individual wages. These include dummy variables for highest level of education completed, single year of age, citizenship status, marital status, whether an individual is Black, Hispanic, Asian, or Other, gender, and the interaction of gender with marital status and the race/ethnicity dummies; the regression also includes survey year dummies and a continuous variable for the usual hours the individual works per week. ${ }^{6}$ Since the equation includes individual controls for education and other characteristics, the effects of metropolitan area level variables can be interpreted as resulting from external effects.

The metropolitan area characteristics include two local human capital stock measures and several control variables. The two human capital stock measures are 1) the percentage of the adult (age 25+) population with a bachelor's degree in a STEM field and 2) the percentage of the adult population with a bachelor's degree in a non-STEM field. I classify ACS college major fields as STEM based on definitions used by the U.S. Immigration and Customs Enforcement; a list of ACS majors classified as STEM is provided in Appendix Table A. These two human capital measures sum to equal the percentage of the population with a four-year college degree, the primary human capital measure used by Moretti, Glaeser, and many others. An important

\footnotetext{
${ }^{5}$ Wage income is converted to 2011 dollars using the CPI before converting to logs.

${ }^{6}$ Results below are robust to using log "hourly wages" computed by dividing annual wage income by the product of weeks worked and usual hours worked, which should be expected since the sample is already restricted to full-time full-year workers.
} 
caveat to these human capital measures is that the ACS only reports the major for an individual's bachelor's degree. Graduate degrees create valuable human capital as well and many people obtain graduate degrees in different fields than their undergraduate degrees. I cannot isolate the effects of graduate degrees in STEM and non-STEM fields, but the primary human capital measure used in the research literature has been the percentage of the population with a bachelor's degree, and this paper is able to separate the effects of bachelor's degrees into the effects from STEM degrees and the effects from non-STEM degrees.

The additional metropolitan area controls include the unemployment rate in the area ${ }^{7}$, the percentage of the population that is foreign born, the percentage of the population that is age 65 or older, the $\log$ of population in the metro area in 2010 , the distance to a metro area with a population of at least 250 thousand people, the incremental distance to a metro area with at least 500 thousand people, the incremental distance to a metro area with at least 1.5 million people, the mean January temperature, the mean July temperature, the mean annual precipitation, and three dummy variables for census region. ${ }^{8}$ The Northeast is the omitted region. The 2010 population comes from the Census Bureau. The temperature and precipitation variables are from the 2007 County and City Data Book with metropolitan areas assigned the values of their principal cities. The distances to progressively larger metropolitan area variables were computed

\footnotetext{
${ }^{7}$ Unfortunately, the time period for the available data overlaps with the Great Recession and slow economic recovery that followed. Including the metro area unemployment rate should largely account for regional differences in demand shocks. However, it seems possible that the effects of several variables on wages could differ between periods of good and bad macroeconomic conditions. Future research should revisit whether estimates of human capital externalities depend on broader macroeconomic conditions, but the current study is unable to do so because there is no good macroeconomic period to study that also has regional measures of human capital by college major. ${ }^{8}$ The climate variables and region dummies are included in part to account for amenities (DuMond, Hirsch, and Macpherson 1999). These variables can affect both wages and migration decisions, so I include them as controls to reduce concerns about worker sorting into high amenity areas. The region dummies also account for other unobserved differences across regions.
} 
similarly to Partridge, Rickman, Ali and Olfert $(2009,2010){ }^{9}$ A metro area exceeding a given population threshold itself has a distance of zero. The remaining metropolitan area variables are computed as three year averages using the 2009-2011 ACS. One could alternatively construct annual measures of these variables but annual fluctuations are likely to be largely driven by sampling error. The true variables should not change much over a short time period, especially the human capital variables, so averaging over the three years helps reduce measurement error to obtain more precise estimates.

Admittedly, many of these metropolitan area variables are potentially endogenous, including the human capital variables. ${ }^{10}$ Other researchers have attempted to account for endogeneity in the human capital stock through various strategies including instrumental variables and time-differencing, but neither approach is followed here. First, time-differencing is impractical because the measures used are not available before 2009 and differencing over the very short time period available would produce mostly noise. Second, most of the instrumental variable strategies that have been used are intended to predict changes over time and are less suited for exogenously predicting cross-sectional differences in human capital levels; the main exception is the land grant university instrument introduced by Moretti (2004b). However, the current study examines two distinct yet highly correlated measures of the human capital stock; the correlation between the two human capital measures is 0.78 . A valid instrumental variables strategy would require at least two exogenous instruments that are thought to differentially affect the two human capital variables with strong correlations so that the second stage equation is

\footnotetext{
${ }^{9}$ Partridge et al. $(2009,2010)$ show that proximity to larger metro areas increases wages for workers in nearby areas suggesting that agglomeration economies may spillover across metro areas.

${ }^{10}$ It should also be noted that there is a long list of other metro area variables that could be potentially included as controls. In particular, one could include occupational measures as suggested by Florida (2002). However, the focus of the current study is to examine the separate effects of STEM graduates and non-STEM graduates. Including variables that are very highly correlated with these two human capital measures would likely hinder the ability to estimate and interpret separate effects due to a high degree of multicollinearity.
} 
identified. Given the difficulty of finding suitable instruments for this setting, the preferred approach in this paper is to use Ordinary Least Squares (OLS) but recognize that the coefficient estimates may not necessarily measure causal effects. Still, the current approach has the potential to uncover an important relationship between local wages and human capital levels that has previously gone unobserved.

\section{Empirical Results}

The wage equation is estimated separately for three types of workers: 1) those with less than a bachelor's degree, 2) those with a STEM degree, and 3) those with a non-STEM degree. Thus, the external effects that STEM and non-STEM graduates have on other workers are allowed to differ by the amount and type of human capital the recipient has. I am especially interested in how STEM graduates affect non-graduates and graduates with degrees in nonSTEM fields.

\subsection{Effects on Non-College Graduates}

The estimated external effects of the two local human capital stock measures on the wages of non-college graduates are reported in Table 2. Estimates are reported for specifications both without and with the additional metro area controls, but all regressions include the individual level controls. Results for the individual and additional metro area characteristics are omitted.

The first column of Table 2 reports the results without the additional metro area controls. Both human capital variables have positive coefficients and are statistically significant at the 1 percent level. The percentage of the population with a STEM degree has a coefficient of 1.630 , 
and the percentage of the population with a non-STEM degree has a coefficient of 0.632 .

Controlling for the additional city controls in the second column reduces the coefficients to 1.309 and 0.291 , respectively, and the latter coefficient is now only statistically significant at the 10 percent level. Even with the additional controls, these human capital measures appear to have positive external effects on the wages of workers who never earned a college degree.

The magnitudes of the results with the additional controls suggests that a one percentage point increase in the population with a STEM degree increases the wages of non-college graduates by 1.31 percent and a one percentage point increase in non-STEM graduates increases the wages of non-college graduates by 0.29 percent. Both are economically meaningful effects that provide empirical support for human capital externalities, but the effect of STEM graduates is considerably larger. The difference in the coefficients is also statistically significant with a p-

value of 0.012 in column 2. The results suggest that both STEM and non-STEM graduates have positive external effects on the wages of workers in their metropolitan area with less than a college degree, but STEM graduates create much larger external benefits for their neighbors and coworkers.

\subsection{Effects on STEM Graduates}

Table 3 reports the effects of the two human capital stock measures on the wages of STEM graduates. The results in the first column, which exclude the additional metro area controls, yield significant coefficients of 2.115 and 0.478 , respectively, for the percentage of STEM and non-STEM graduates in the population. Including the additional metro area controls in column 2 reduces the coefficients to 1.971 and -0.070 , and the latter coefficient is not significant. The STEM percentage coefficient is statistically significantly larger than the non- 
STEM percentage coefficient in both columns. The second column results suggest that a one percentage point increase in STEM graduates increases the wages of STEM workers by 1.97 percent.

It appears that having a large stock of STEM graduates in one's local labor market benefits other STEM graduates, but a large stock of non-STEM graduates likely does not benefit STEM graduates. The latter result is actually somewhat surprising. One explanation is that STEM graduates might benefit from other STEM graduates through agglomeration economies that are field-specific. For example, the transfer of knowledge and skills through human capital spillovers may occur from one STEM graduate to another but not from non-STEM graduates to STEM graduates; i.e., STEM graduates may not have much to learn from non-STEM graduates. However, there is an important alternative explanation. Workers may sort into areas that offer the highest return on their skills, and STEM graduates may sort into areas that pay high wage premiums for STEM graduates, which would induce a positive correlation between the share of the population with a STEM degree and the wages of STEM graduates. These results for the effects on STEM graduates should be interpreted with some caution.

\subsection{Effects on Non-STEM Graduates}

Table 4 reports the effects of the two human capital stock measures on the wages of college graduates with degrees in non-STEM fields. The first column again excludes the additional metro area controls, and the second column includes them. The first column yields a statistically insignificant coefficient for the STEM percentage of 0.751 and a statistically significant coefficient for the non-STEM percentage of 1.623. However, adding the additional controls in the second column increases the coefficient on the STEM percentage to 0.977 , which 
is now statistically significant, and decreases the coefficient on the non-STEM percentage to 0.670. In both regressions, the coefficients on the two variables are not statistically significantly different from each other.

According to the second column results, both STEM and non-STEM graduates generate positive externalities on the wages of non-STEM graduates, and the effects are of similar magnitude. College graduates with degrees in non-STEM fields appear to benefit from proximity to all college graduates, both STEM and non-STEM. ${ }^{11}$ There are also some interesting suggestions comparing the results across the three groups of workers. In particular, non-STEM graduates appear to benefit from proximity to other non-STEM graduates more than either of the other two groups do. There are again some concerns that non-STEM graduates could be sorting into metro areas that offer especially high wages for workers with their particular skills, and this could be driving the relationship between the percentage of non-STEM graduates and their wages. However, it is interesting that non-STEM graduates benefit from being near STEM graduates even controlling for the level of non-STEM graduates in the area. This seems to suggest that the spillovers from STEM graduates to non-STEM graduates are not simply due to sorting by non-STEM graduates.

\subsection{Adding Individual Controls for Industry and Occupation}

The preceding analysis includes a number of individual and locational controls.

However, it does not control for industry and occupation because these are a priori thought to be important mechanisms through which human capital externalities operate. High human capital workers create new production ideas and demand local products that stimulate local employment

\footnotetext{
${ }^{11}$ In another study using the ACS, Cunningham, Patton, and Reed (2013) find that non-STEM graduates also experience a steeper city size wage gradient than graduates in STEM fields.
} 
in certain industries and occupations. However, there is some concern that the previous results could be driven by regional industrial and occupational mix differences that are correlated with but not caused by local human capital levels. To address this, I next examine the robustness of the results to including individual controls for industry and occupation; specifically, I add to the previous regressions 14 industry dummies and 18 occupation dummies. The results for all education groups are reported in Table 5.

As one would expect, the coefficients in Table 5 are generally smaller than the corresponding estimates in Table 2-4. The difference is especially notable for STEM graduate results in columns 3 and 4. Importantly, though the results are for the most part qualitatively similar to the prior tables. The percentage of the population with a STEM degree has a positive external effect on the earnings of all groups, and the STEM externalities are still considerably larger than non-STEM externalities for non-college graduates and STEM graduates. Thus, STEM graduates still appear to have important effects on other workers in nearby areas even after controlling for individual industry and occupation.

\subsection{Alternative Human Capital Measures}

One potential limitation with the main analysis in this paper is that the two human capital measures are highly correlated and there may be some difficulty separating out the separate external effects of graduates in STEM and non-STEM fields. Furthermore, the primary variable of interest, the percentage of the adult population with a STEM degree, combines both the amount of human capital and the type of human capital in an area. It may also be of interest to examine how sensitive the implications are to examining alternative measures of human capital. I next use two different human capital variables that examine the importance of STEM graduates 
in a different way. The two alternative measures are 1) the percentage of the adult population with a college degree and 2) the percentage of college graduates with a degree in a STEM field. The first variable is the typical education-based human capital measure used by previous researchers (e.g. Moretti 2004b), which is the sum of the two main explanatory variables in this study. The second variable measures the external effects of having more STEM graduates without increasing the overall level of human capital. The correlation between these two variables is 0.53 , which is relatively large but certainly small enough to uncover separate effects with 325 metropolitan areas. These two alternative human capital measures are now included in the regressions instead of the original two measures; the other specifications are the same as in Tables 2-4. ${ }^{12}$

The results for the two alternative human capital measures are reported in Table 6. The percentage of the population with a college degree has a significantly positive effect in all six columns, and the magnitude does vary somewhat across columns. More interesting for the current paper is the effect of the second variable, the percentage of college graduates with a degree in a STEM field, which I refer to as the STEM share. The STEM share has a significantly positive coefficient on the wages of non-college graduates and STEM graduates in columns 1-4 but has a relatively small insignificant effect on college graduates in non-STEM fields in columns 5-6. Though the specification differs, this actually tells a similar story to the results in Table 2-4. Having more college graduates in the area creates external wage benefits for other workers, but having more STEM graduates in the area is especially beneficial for non-

\footnotetext{
${ }^{12}$ The original human capital measures are the preferred ones because the alternative specification in some ways confounds the effects of STEM and non-STEM graduates by combining them in a variable measuring the percentage of the population with any college degree. For example, a positive coefficient on both variables in the alternative specification could make it appear that non-STEM graduates create positive externalities, even though they might not. The original specification better separates the external effects of STEM and non-STEM graduates and allows for a more intuitive interpretation. Still, the alternative specification is a useful exercise for examining the robustness of the results.
} 
college graduates and for STEM graduates. Even controlling for the overall level of human capital, replacing some non-STEM graduates with STEM graduates increases the wages of noncollege graduates and STEM graduates. Thus, it is not just the level of human capital that matters, but also the type of human capital. STEM graduates generally create the largest external benefits.

\section{Conclusion}

This study has attempted to sharpen our understanding of human capital externalities by separating local human capital levels into two components: the percentage of the local population with a college degree in a STEM field, and the percentage with a degree in a nonSTEM field. The external effects of these two human capital measures on the wage income of other workers are examined for three different types of recipient: workers without a bachelor's degree, workers with a bachelor's degree in a STEM field, and workers with a bachelor's degree in a non-STEM field.

Both STEM and non-STEM graduates appear to generate human capital externalities that increase the wages of other workers in the same labor market. However, proximity to STEM graduates appears to create much larger external benefits than proximity to non-STEM graduates. STEM graduates also benefit all three types of workers considered, while non-STEM graduates do not benefit STEM graduates. These results are robust to including a number of individual and metropolitan area control variables.

Given that I am unable to observe completely random variation in local human capital levels, the results should be interpreted with some caution. Workers may sort into local labor markets that most benefit them and the workers with the greatest skills and education may have 
the most to gain from migration (Wozniak 2010; Malamud and Wozniak 2012). However, the analysis here focuses on external effects of human capital, i.e., how workers' human capital affects the wages of other workers with very different levels and types of human capital. If worker sorting were the explanation driving the results, one would not necessarily expect there to be such large effects of STEM graduates on the wages of workers without college degrees and workers with degrees in non-STEM fields, especially after controlling for the stock of graduates in non-STEM fields and a number of other variables. One would also not necessarily expect non-college graduates to benefit significantly more from proximity to STEM graduates than from proximity to non-STEM graduates. These pieces of evidence suggest that there is something unique and important about having STEM graduates in one's labor market that creates positive wage externalities, even for workers who are not themselves STEM graduates. Popular perceptions and economic theories view skilled workers as the engines of innovation and economic growth. College graduates are viewed as good for economic development, but STEM graduates are thought to be even better. The empirical results in this study are consistent with those widely held prior beliefs.

The results in this study suggest that the social benefits of STEM education considerably exceed the private benefits. Furthermore, while the current analysis measures human capital externalities received by other workers in the same metropolitan area, the external benefits of human capital could also spill over across metropolitan area boundaries, meaning the benefits to the nation could exceed the benefits to particular metropolitan areas. Thus, there is likely an important role for local, state, and national government policies intended to increase the number and share of STEM graduates in the labor force. This study cannot assess the effectiveness of any particular policy related to STEM graduates, but this seems an important area for future 
research and experimentation. Areas can increase the local stock of STEM graduates by educating more local residents in STEM fields, discouraging locally educated STEM graduates from leaving the area, and encouraging STEM graduates from other areas to move to the area. The geographic redistribution of STEM graduates likely hurts losing areas and may create broader social costs if resources spent on recruiting and migration are not efficiency-enhancing, but it is likely to have large benefits for the winning areas and the STEM graduates themselves. Thus, there are certainly benefits to regional and even national policymakers to better understanding how to attract STEM graduates to their areas. For the U.S. this may mean allowing increased immigration quotas or streamlining the visa application process for foreignborn STEM graduates. For regions this may mean improving the public services and amenities that they have to offer, both to domestic and foreign-born STEM graduates.

Instead of trying to alter the location decisions of STEM graduates, another alternative is to increase domestic production of STEM graduates. This is not to suggest that everyone should be a STEM graduate or that graduates in other fields are not socially beneficial, but the results in this study do suggest that reasonable increases in the stock of STEM graduates can have considerable social benefits. There is a growing body of research examining the factors that affect student decisions to go to college and the factors that affect decisions to major in STEM fields, but there is still much that is unknown and a need for additional research. STEM fields are generally more challenging than other majors (Betts and Morrell 1999; Rask 2010; Arcidiacono, Aucejo, and Spenner 2012), and many potential STEM graduates decide not to complete a STEM degree because they lack sufficient preparation in math and sciences (Federman 2007; Griffith 2010; Kokkelenberg and Sinha 2010; Ost 2010; Rask 2010). Better student preparation in primary and secondary education is a useful goal, but the best policies to 
achieve that are unclear. Researchers have also observed that women and minorities are underrepresented in STEM degree fields but there is an incomplete understanding why (Griffith 2010; Price 2010; Arcidiacono, Aucejo, and Hotz 2013). Policies that encourage historically underrepresented groups to major in STEM fields may be able to increase the stock of STEM graduates and serve other social goals. Finally, there is evidence that some potential STEM students respond to incentives provided by financial aid programs (Denning and Turley 2013; Sjoquist and Winters 2013). Scholarship programs specifically targeted to STEM fields may be able to increase STEM education for students at the margin of majoring in STEM or not. Combining several well-designed policies has the potential to meaningfully increase STEM education and the resulting benefits to society. 


\section{References}

Abel, J.R., Deitz, R. 2012a. Do colleges and universities increase their region's human capital? Journal of Economic Geography, 12(3): 667-691.

Abel, J., Deitz, R. 2012b. Agglomeration and job matching among college graduates. Federal Reserve Bank of New York Staff Report No. 587.

Abreu, M., Faggian, A., Comunian, R., McCann, P. 2012. "Life is short, art is long": The persistent wage gap between Bohemian and non-Bohemian graduates. Annals of Regional Science, 49: 305-321.

Acs, Z., Armington, C. 2006. Entrepreneurship, Geography and American Economic Growth. Cambridge University Press, New York.

Arcidiacono, P., Aucejo, E.M., Hotz, V.J. 2013. University differences in the graduation of minorities in STEM fields: Evidence from California. NBER Working Paper No. 18799.

Arcidiacono, P., Aucejo, E.M., Spenner, K. 2012. What happens after enrollment? An analysis of the time path of racial differences in GPA and major choice. IZA Journal of Labor Economics, 1(5): 1-24.

Atkinson, R.D., Mayo, M. 2010. Refueling the U.S. Innovation Economy: Fresh Approaches to Science, Technology, Engineering and Mathematics (STEM) Education. Information Technology and Innovation Foundation Report.

Bauer, P., Schweitzer, M.E., Shane, S. 2012. Knowledge matters: The long-run determinants of state income growth. Journal of Regional Science, 52(2): 240-255.

Berry, C.R., Glaeser, E.L. 2005. The divergence of human capital levels across cities. Papers in Regional Science, 84: 407-444. 
Betts, J.R., Morell, D. 1999. The determinants of undergraduate grade point average: The relative importance of family background, high school resources, and peer group effects. Journal of Human Resources, 34: 268-93.

Brown, W.M., Scott, D.M. 2012. Human capital location choice: Accounting for amenities and thick labor markets. Journal of Regional Science, 52(5): 787-808.

Comunian, R., Faggian, A., Li, Q.C. 2010. Unrewarded careers in the creative class: The strange case of Bohemian graduates. Papers in Regional Science, 89: 389-410.

Crispin, L., Saha, S.B., Weinberg, B.A. 2010. Innovation spillovers in industrial cities. Federal Reserve Bank of Cleveland Working Paper No. 10-25.

Cunningham, C., Patton, M., Reed, R. 2013. Heterogeneous returns to knowledge exchange: Evidence from the urban wage premium. Federal Reserve Bank of Atlanta Working Paper.

Denning, J.T., Turley, P. 2013. Was that SMART? Institutional financial incentives and field of study. Working Paper.

Donegan, M., Drucker, J., Goldstein, H., Lowe, N., Malizia, E. 2008. Which indicators explain metropolitan economic performance best? Traditional or creative class. Journal of the American Planning Association, 74(2): 180-195.

DuMond, J.M., Hirsch, B.T., Macpherson D.A. 1999. Wage differentials across labor markets and workers: Does cost of living matter? Economic Inquiry, 37(4): 577-598.

Echeverri-Carroll, E., Ayala, S.G. 2009. Wage differentials and the spatial concentration of hightechnology industries. Papers in Regional Science, 88(3): 623-641.

Faggian, A., Partridge, M.D., Malecki, E. 2011. Creating an environment for economic growth: Human capital, creativity and entrepreneurship in the USA. Working Paper. 
Fallah, B., Partridge, M.D., Rickman, D.S. 2013. Geography and high-tech employment growth in US counties. Journal of Economics Geography. Forthcoming.

Federman, M. 2007. State graduation requirements, high school course taking, and choosing a technical college major. The B.E. Journal of Economic Analysis \& Policy, 7(1): Article 4.

Florida, R. 2002. The Rise of the Creative Class. Basic Books, New York.

Florida, R., Mellander, C., Stolarick, K. 2008. Inside the black box of regional developmenthuman capital, the creative class, and tolerance. Journal of Economic Geography, 8: 615649.

Glaeser, E.L. 2005. Review of Richard Florida's The Rise of the Creative Class. Regional Science and Urban Economics, 35(5): 593-596.

Glaeser, E.L., Kerr, W.R., Ponzetto, G.A.M. 2010. Clusters of entrepreneurship, Journal of Urban Economics, 67(1): 150-168.

Glaeser, E.L., Saiz, A. 2004. The rise of the skilled city. Brookings-Wharton Papers on Urban Affairs, 47-94.

Glaeser, E.L., Scheinkman, J., Shleifer, A. 1995. Economic growth in a cross-section of cities. Journal of Monetary Economics, 36: 117-143.

Gottlieb, P.D., Joseph, G. 2006. College-to-work migration of technology graduates and holders of doctorates within the United States. Journal of Regional Science, 46: 627-659.

Griffith, A. 2010. Persistence of women and minorities in STEM field majors: Is it the school that matters? Economics of Education Review. 29 (2010): 911-922.

Henderson, J.V. 2007. Understanding knowledge spillovers. Regional Science and Urban Economics, 37: 497-508. 
Iranzo, S., Peri, G. 2009. Schooling externalities, technology, and productivity: Theory and evidence from U.S. states. Review of Economics and Statistics, 91: 420-431.

Kokkelenberg, E.C., Sinha, E. 2010. Who succeeds in STEM studies? An analysis of Binghamton University undergraduate students. Economics of Education Review, 29(6): 935-946.

Lange, F., Topel, R. 2006. The social value of education and human capital. In: Hanushek, E., Welch, F. (Eds.), Handbook of the Economics of Education. Elsevier, Amsterdam, pp. 459-509.

Malamud, O., Wozniak, A.K. 2012. The impact of college on migration: Evidence from the Vietnam generation. Journal of Human Resources, 47(4): 913-950.

Marrocu, E., Paci, R. 2012. Education or creativity: What matters most for economic performance? Economic Geography, 88: 369-401.

McGranahan, D.A., Wojan, T.R. 2007. Recasting the creative class to examine growth processes in rural and urban countries. Regional Studies, 41(2): 197-216.

Mellander, C., Florida, R. 2007. The creative class or human capital? Explaining regional development in Sweden. CESIS Working Paper No. 79.

Miguélez, E., Moreno, R. 2013. What attracts knowledge workers? The role of space and social networks. Journal of Regional Science, Forthcoming.

Moretti, E. 2004a. Human capital externalities in cities. In: Henderson, J.V., Thisse, J.F. (Eds.), Handbook of Regional and Urban Economics, Vol. 4. Elsevier, Amsterdam, pp. 22432291.

Moretti, E. 2004b. Estimating the social return to higher education: Evidence from longitudinal and repeated cross-sectional data. Journal of Econometrics, 121: 175-212. 
Moretti, E. 2004c. Workers' education, spillovers and productivity: Evidence from plant-level production functions, American Economic Review, 94(3): 656-690.

National Academies. 2010. Rising Above the Gathering Storm: Rapidly Approaching Category 5: Revised. 2005 Rising Above the Storm Committee. Washington, DC: National Academies Press.

Ost, B. 2010. The role of peers and grades in determining major persistence in the sciences. Economics of Education Review, 29(6): 923-934.

Paci, R., Marrocu, E. 2013. Knowledge assets and regional performance. Growth and Change, 44(2): $228-257$.

Partridge, M.D., Rickman, D.S., Ali, K., Olfert, M.R. 2009. Agglomeration spillovers and wage and housing cost gradients across the urban hierarchy. Journal of International Economics, 78(1): 126-140.

Partridge, M.D., Rickman, D.S., Ali, K., Olfert, M.R. 2010. Recent spatial growth dynamics in wages and housing costs: Proximity to urban production externalities and consumer amenities. Regional Science and Urban Economics, 40(6): 440-452.

Peri, G., Shih, K., Sparber, C. 2013. STEM Workers, H1B Visas and Productivity in US Cities. UC-Davis Working Paper.

Price, J. 2010. The effect of instructor race and gender on student persistence in STEM fields. Economics of Education Review, 29(6): 901-910.

Rask, K. 2010. Attrition in STEM fields at a liberal arts college: The importance of grades and pre-collegiate preferences. Economics of Education Review, 29(6): 892-900.

Rauch, J.E. 1993. Productivity gains from geographic concentration of human capital: Evidence from the cities. Journal of Urban Economics, 34: 380-400. 
Robst, J. 2007a. Education and job match: The relatedness of college major and work. Economics of Education Review, 26(4): 397-407.

Robst, J. 2007b. Education, college major, and job match: Gender differences in reasons for mismatch. Education Economics, 15(2): 159-175.

Rodríguez-Pose, A. 1999. Innovation prone and innovation averse societies: Economic performance in Europe. Growth and Change, 30: 75-105.

Rodríguez-Pose, A., Crescenzi, R. 2008. Research and development, spillovers, innovation systems, and the genesis of regional growth in Europe. Regional Studies, 42(1): 51-67.

Rodríguez-Pose, A., Vilalta-Bufi, M. 2005. Education, migration, and job satisfaction: The regional returns of human capital in the EU. Journal of Economic Geography, 5(5): 545566.

Ruggles, S.J., Alexander,T., Genadek, K., Goeken, R., Schroeder, M.B., Sobek, M. 2010. Integrated Public Use Microdata Series: Version 5.0 [Machine-readable database]. Minneapolis: University of Minnesota.

Shapiro, J.M. 2006. Smart cities: Quality of life, productivity, and the growth effects of human capital. Review of Economics and Statistics, 88: 324-335.

Simon, C.J. 1998. Human capital and metropolitan employment growth. Journal of Urban Economics, 43: 223-243.

Simon, C.J. 2004. Industrial reallocation across U.S. cities, 1977-97. Journal of Urban Economics, 56: 119-143.

Simon, C.J., Nardinelli, C. 2002. Human capital and the rise of American cities, 1900-1990. Regional Science and Urban Economics, 32: 59-96. 
Sjoquist, D.L., Winters, J.V. 2013. State merit-aid programs and college major: A focus on STEM. IZA Discussion Paper 7381.

Stephens, H.M., Partridge, M.D. 2011. Do entrepreneurs enhance economic growth in lagging regions? Growth and Change, 42: 431-465.

Stephens, H.M., Partridge, M.D., Faggian, A. 2013. Innovation, entrepreneurship and economic growth in lagging regions. Journal of Regional Science. Forthcoming.

Storper, M., Scott, A.J. 2009. Rethinking human capital, creativity and urban growth. Journal of Economic Geography, 9: 147-167.

Whisler, R.L., Waldorf, B.S., Mulligan, G.F., Plane, D.A. 2008. Quality of life and the migration of the college-educated: A life-course approach. Growth and Change, 39: 58-94.

Winters, J.V. 2011 a. Human capital, higher education institutions, and quality of life. Regional Science and Urban Economics, 41(5): 446-454.

Winters, J.V. 2011b. Why are smart cities growing? Who moves and who stays. Journal of Regional Science, 51(2): 253-270.

Winters, J.V. 2013. Human capital externalities and employment differences across metropolitan areas of the USA. Journal of Economic Geography, 13(5): 799-822.

Wozniak, A. 2010. Are college graduates more responsive to distant labor market opportunities? Journal of Human Resources, 45(4): 944-70. 
Table 1: Summary Statistics

\begin{tabular}{|c|c|c|c|c|}
\hline Variable & Mean & Std. Dev. & Min & Max \\
\hline Percentage of Population with a STEM Degree & 0.073 & 0.027 & 0.020 & 0.206 \\
\hline Percentage of Population with a Non-STEM Degree & 0.237 & 0.051 & 0.094 & 0.445 \\
\hline Unemployment Rate & 0.086 & 0.019 & 0.030 & 0.154 \\
\hline Percentage of Population Foreign-Born & 0.207 & 0.143 & 0.008 & 0.701 \\
\hline Percentage of Population Ages 65+ & 0.153 & 0.029 & 0.088 & 0.390 \\
\hline Log Population & 14.329 & 1.149 & 11.2 & 16.1 \\
\hline Distance to metro w/ pop $>250 \mathrm{~K}$ & 12.657 & 41.192 & 0 & 384.1 \\
\hline Incremental Distance to metro w/ pop $>500 \mathrm{~K}$ & 10.935 & 59.491 & 0 & 1430.5 \\
\hline Incremental Distance to metro w/ pop $>1500 \mathrm{~K}$ & 39.671 & 164.238 & 0 & 2394.0 \\
\hline Mean January Temperature & 38.792 & 13.163 & 5.3 & 73.0 \\
\hline Mean July Temperature & 77.039 & 5.739 & 58.4 & 94.1 \\
\hline Mean Annual Precipitation & 36.882 & 14.103 & 3.01 & 66.3 \\
\hline Midwest Region Dummy & 0.203 & 0.402 & 0 & 1 \\
\hline South Region Dummy & 0.363 & 0.481 & 0 & 1 \\
\hline West Region Dummy & 0.244 & 0.430 & 0 & 1 \\
\hline Log Real Annual Wage Income & 10.795 & 0.691 & 1.386 & 13.418 \\
\hline Usual Hours Worked Per Week & 44.903 & 8.163 & 40 & 99 \\
\hline Age & 40.419 & 8.781 & 25 & 55 \\
\hline Highest Education - Some High School & 0.043 & 0.202 & 0 & 1 \\
\hline Highest Education - HS Diploma & 0.209 & 0.407 & 0 & 1 \\
\hline Highest Education - Some College, No Degree & 0.217 & 0.412 & 0 & 1 \\
\hline Highest Education - Two-Year College Degree & 0.091 & 0.287 & 0 & 1 \\
\hline Highest Education - Bachelor's Degree & 0.260 & 0.439 & 0 & 1 \\
\hline Highest Education - Master's Degree & 0.106 & 0.308 & 0 & 1 \\
\hline Highest Education - Professional Degree & 0.029 & 0.169 & 0 & 1 \\
\hline Highest Education - Doctoral Degree & 0.018 & 0.132 & 0 & 1 \\
\hline Naturalized Citizen & 0.093 & 0.290 & 0 & 1 \\
\hline Non-Citizen & 0.098 & 0.297 & 0 & 1 \\
\hline Female & 0.414 & 0.493 & 0 & 1 \\
\hline Married & 0.622 & 0.485 & 0 & 1 \\
\hline Married Female & 0.229 & 0.420 & 0 & 1 \\
\hline Black & 0.104 & 0.306 & 0 & 1 \\
\hline Black Female & 0.054 & 0.227 & 0 & 1 \\
\hline Asian & 0.069 & 0.253 & 0 & 1 \\
\hline Asian Female & 0.029 & 0.168 & 0 & 1 \\
\hline Hispanic & 0.156 & 0.363 & 0 & 1 \\
\hline Hispanic Female & 0.059 & 0.237 & 0 & 1 \\
\hline Other Non-White & 0.018 & 0.134 & 0 & 1 \\
\hline Other Non-White Female & 0.008 & 0.090 & 0 & 1 \\
\hline Year 2010 Dummy & 0.324 & 0.468 & 0 & 1 \\
\hline Year 2011 Dummy & 0.326 & 0.469 & 0 & 1 \\
\hline
\end{tabular}

Notes: the full sample includes 1,241,592 full-time full year workers in 325 metropolitan areas. 
Table 2: External Effects of STEM and Non-STEM Graduates on Wages of Non-College Graduates

Percentage of Population with a STEM Degree

Percentage of Population with a Non-STEM Degree
(1)

(2)

$\begin{array}{cc}1.630 * * * & 1.309 * * * \\ (0.364) & (0.304) \\ 0.632 * * * & 0.291 * \\ (0.222) & (0.170) \\ & \\ \mathrm{p}=0.060 & \mathrm{p}=0.012 \\ \text { Yes } & \text { Yes } \\ \text { No } & \text { Yes }\end{array}$

Difference in Coefficients P-value

Individual Controls

Metropolitan Area Controls

Note: Individual and metro area controls are listed in Table 1.

*Significant at $10 \%$ level; ***Significant at $1 \%$ level. 
Table 3: External Effects of STEM and Non-STEM Graduates on Wages of STEM Graduates

(1)

(2)

Percentage of Population with a STEM Degree

$2.115^{* * *} \quad 1.971 * * *$

$(0.378) \quad(0.257)$

Percentage of Population with a Non-STEM Degree

$0.478 * \quad-0.070$

$(0.243) \quad(0.228)$

Difference in Coefficients P-value

$\mathrm{p}=0.005 \quad \mathrm{p}=0.000$

Individual Controls

Yes Yes

Metropolitan Area Controls

No Yes

Note: Individual and metro area controls are listed in Table 1.

*Significant at $10 \%$ level; $* * *$ Significant at $1 \%$ level. 
Table 4: External Effects of STEM and Non-STEM Graduates on Wages of Non-STEM Graduates

\begin{tabular}{lcc} 
& $(1)$ & $(2)$ \\
\hline Percentage of Population with a STEM Degree & 0.751 & $0.977^{* * *}$ \\
& $(1.015)$ & $(0.294)$ \\
Percentage of Population with a Non-STEM Degree & $1.623^{* * *}$ & $0.670^{* * *}$ \\
& $(0.529)$ & $(0.245)$ \\
& & \\
Difference in Coefficients P-value & $\mathrm{p}=0.567$ & $\mathrm{p}=0.519$ \\
Individual Controls & Yes & Yes \\
Metropolitan Area Controls & No & Yes \\
\hline
\end{tabular}

Note: Individual and metro area controls are listed in Table 1.

***Significant at $1 \%$ level. 
Table 5: External Wage Effects Controlling for Individual Industry and Occupation
(1)
(2)
(3)
(4)
(5)
(6)

Non-College Grads STEM Graduates Non-STEM Graduates

\begin{tabular}{lccccccc}
\hline \% of Pop with a STEM Degree & $1.384 * * *$ & $1.221 * * *$ & $1.622 * * *$ & $1.295 * * *$ & 0.613 & $0.773 * * *$ \\
& $(0.354)$ & $(0.279)$ & $(0.316)$ & $(0.212)$ & $(0.909)$ & $(0.266)$ \\
& $0.655^{* * *}$ & $0.352 * *$ & $0.523 * *$ & 0.184 & $1.369 * * *$ & $0.562^{* *}$ \\
& $(0.213)$ & $(0.154)$ & $(0.212)$ & $(0.175)$ & $(0.474)$ & $(0.220)$
\end{tabular}

Difference in Coefficients P-value

\begin{tabular}{cccccc}
$\mathrm{p}=0.159$ & $\mathrm{p}=0.018$ & $\mathrm{p}=0.023$ & $\mathrm{p}=0.000$ & $\mathrm{p}=0.578$ & $\mathrm{p}=0.619$ \\
Yes & Yes & Yes & Yes & Yes & Yes \\
Yes & Yes & Yes & Yes & Yes & Yes \\
No & Yes & No & Yes & No & Yes \\
\hline
\end{tabular}

Base Individual Controls

Individual Industry and Occupation

Metropolitan Area Controls

Note: Individual and metro area controls are listed in Table 1.

**Significant at 5\% level; ***Significant at $1 \%$ level. 
Table 6: External Wage Effects Using Alternative Human Capital Measures
(1)
(2)
(3)
(4)
(5)
(6)

Non-College Grads STEM Graduates Non-STEM Graduates

\begin{tabular}{lccccccc}
\hline \% of Graduates with STEM Degree & $0.348 *$ & $0.328 * *$ & $0.701 * * *$ & $0.832 * * *$ & -0.254 & 0.140 \\
& $(0.181)$ & $(0.141)$ & $(0.250)$ & $(0.146)$ & $(0.555)$ & $(0.162)$ \\
& $0.854 * * *$ & $0.537 * *$ & $0.844 * * *$ & $0.412 * * *$ & $1.408 * * *$ & $0.734 * * *$ \\
\% of Pop with a College Degree & $(0.139)$ & $(0.126)$ & $(0.138)$ & $(0.155)$ & $(0.216)$ & $(0.157)$
\end{tabular}

\begin{tabular}{lcccccc} 
Individual Controls & Yes & Yes & Yes & Yes & Yes & Yes \\
Metropolitan Area Controls & No & Yes & No & Yes & No & Yes \\
\hline
\end{tabular}

Note: Individual and metro area controls are listed in Table 1.

*Significant at $10 \%$ level; **Significant at $5 \%$ level; ***Significant at $1 \%$ level. 
Table A: List of ACS Majors Classified as STEM

\begin{tabular}{|c|c|c|c|}
\hline \multicolumn{4}{|c|}{ ACS Code and Description } \\
\hline 1103 & Animal Sciences & 2504 & Mechanical Engineering Related Technologies \\
\hline 1104 & Food Science & 2599 & Miscellaneous Engineering Technologies \\
\hline 1105 & Plant Science and Agronomy & 3600 & Biology \\
\hline 1106 & Soil Science & 3601 & Biochemical Sciences \\
\hline 1301 & Environmental Science & 3602 & Botany \\
\hline 1302 & Forestry & 3603 & Molecular Biology \\
\hline 2001 & Communication Technologies & 3604 & Ecology \\
\hline 2100 & Computer and Information Systems & 3605 & Genetics \\
\hline 2101 & Computer Programming \& Data Processing & 3606 & Microbiology \\
\hline 2102 & Computer Science & 3607 & Pharmacology \\
\hline 2105 & Information Sciences & 3608 & Physiology \\
\hline 2106 & Computer Information Mgmt. \& Security & 3609 & Zoology \\
\hline 2107 & Computer Networking \& Telecommunications & 3611 & Neuroscience \\
\hline 2400 & General Engineering & 3699 & Miscellaneous Biology \\
\hline 2401 & Aerospace Engineering & 3700 & Mathematics \\
\hline 2402 & Biological Engineering & 3701 & Applied Mathematics \\
\hline 2403 & Architectural Engineering & 3702 & Statistics and Decision Science \\
\hline 2404 & Biomedical Engineering & 3801 & Military Technologies \\
\hline 2405 & Chemical Engineering & 4002 & Nutrition Sciences \\
\hline 2406 & Civil Engineering & 4003 & Neuroscience \\
\hline 2407 & Computer Engineering & 4005 & Mathematics and Computer Science \\
\hline 2408 & Electrical Engineering & 4006 & Cognitive Science and Biopsychology \\
\hline 2409 & Engineering Mechanics, Physics, \& Science & 5000 & Physical Sciences \\
\hline 2410 & Environmental Engineering & 5001 & Astronomy and Astrophysics \\
\hline 2411 & Geological and Geophysical Engineering & 5002 & Atmospheric Sciences and Meteorology \\
\hline 2412 & Industrial and Manufacturing Engineering & 5003 & Chemistry \\
\hline 2413 & Materials Engineering and Materials Science & 5004 & Geology and Earth Science \\
\hline 2414 & Mechanical Engineering & 5005 & Geosciences \\
\hline 2415 & Metallurgical Engineering & 5006 & Oceanography \\
\hline 2416 & Mining and Mineral Engineering & 5007 & Physics \\
\hline 2417 & Naval Architecture and Marine Engineering & 5008 & Materials Science \\
\hline 2418 & Nuclear Engineering & 5098 & Multi-disciplinary or General Science \\
\hline 2419 & Petroleum Engineering & 5102 & Nuclear, Industrial Radiology, \& Biol. Tech. \\
\hline 2499 & Miscellaneous Engineering & 5901 & Transportation Sciences and Technologies \\
\hline 2500 & Engineering Technologies & 6106 & Health and Medical Preparatory Programs \\
\hline 2501 & Engineering and Industrial Management & 6108 & Pharmacy, Pharmaceutical Sciences, \& Admin. \\
\hline 2502 & Electrical Engineering Technology & 6202 & Actuarial Science \\
\hline 2503 & Industrial Production Technologies & 6212 & Management Information Systems \& Statistics \\
\hline
\end{tabular}

